\author{
V International Forum on Teacher Education
}

\title{
Preparing Technology Teachers for Professional Activities in the Information Space of Technological Education
}

\author{
Galina N. Nekrasova*(a), Natalya N. Novikova (b) \\ (a) Vyatka State University, Kirov, Russia
}

(b) Pitirim Sorokin Syktyvkar State University, Syktyvkar, Russia

\begin{abstract}
Current digitalization of education calls for new approaches to teacher training. The study conducted in all Russian regions showed that there is an urgent need to develop a spe-cial training program for technology teachers that would equip them with an adequate in-formation and communications technology (ICT) competence. The new training program needs to be different from the programs developed for teachers of other subjects, since technology as a subject area has specific features with an emphasis on practiceoriented learning and the advanced use of ICT. The study is based on the scientific statements of Russian scientists (Akhmetov, 2008), (Bogatyrev, 2003), (Gotskaya \& Zhuchkov, 2001), (Grinshkun, 2013). The majority of scientific works are devoted to the preparing teachers of computer science, mathematics and physics. The methodological foundations of technology teacher preparation is an urgent task.

The purpose of the study is theoretical substation, creation and implementation of the methodological system, which prepare technology teachers for ICT use at their further pro-fessional activities. The study uses the modern methods of collecting and processing initial information, pedagogical modeling, experimental work, final diagnostics. The experimental work was carried out in 2008-2018. The participants of the pedagogical experiment were 850 technology teachers from 28 Russian regions, 620 students and 57 teachers from 15 universities in Russia, Ukraine and the USA. The result of the research is the system of methodological preparation of technology teachers, which has been tested at the domestic and foreign levels.
\end{abstract}

Key words: information space of technological education, professional activity of tech-nology teacher.

\section{(C) 2019 Galina N. Nekrasova, Natalya N. Novikova}

This is an open access article distributed under the terms of the Creative Commons Attribution License (CC BY 4.0), which permits unrestricted use, distribution, and reproduction in any medium, provided the original author and source are credited.

Published by Kazan Federal University and peer-reviewed under responsibility of IFTE-2019 (V International Forum on Teacher Education) 


\section{Introduction}

The increasing requirements to technology teachers training is the result of the rapid development of both new educational ICT, and information educational space. The analysis of pedagogical practice shows that the direction, content and nature of the technology teachers' professional activity are significantly changing nowadays due to the development of information educational space of technological education (hereinafter ISTE). Today technology teachers should manage modern multimedia and interactive technical devices, use electronic means of assessment and record the results of education, solve new professional tasks in organizing independent and research activities of students using distance, network, mobile technologies, etc.

The foreign researchers (Garet, MS, Porter, AC, Desimone, L., Birman, B., \& Yoon, KS (2001)), (Aceto, S., Dondi, C . \& Marzotto, P. (2010)) pointed out the problem of preparing teachers for the effective use of ICT tools. UNESCO Institute for Information Technologies developed the structure of ICT competence of a teacher (2011).

The following regulatory documents describe new requirements for effective ISTE use by technology teacher: Federal Law "On Education in the Russian Federation" (2012), Federal State Educational Standard of Higher Education (2015) and Professional Standard of Teacher (2013). Describing the bachelor program "Pedagogical education", the Federal State Educational Standard of Higher Education highlights the use of possibilities of education space (including ICT) to ensure the quality education,

During 2008-2018 we have been holding the research to determine the readiness of technology teachers to use ICT for creating the high-quality education space. Technology teachers and bachelor students (major "Pedagogical education") took part in the experimental work. The results of the ascertaining stage of the research revealed the following problems in the system of training technology teachers: the predominant use of traditional methods and forms of education; scattered and disconnected disciplines focused on preparing technology teachers for professional activities in ISTE; lack of common approaches and holistic system of the training.

During the ascertaining stage of the research, we found out that future and practicing technology teachers are not ready to solve professional problems in the context of ISTE. During the pedagogical practice, students experienced difficulties in organizing the educational process using modern ICT tools. We obtained facts confirming that the organization of pedagogical interaction with students in ISTE is mostly episodic. Technology teachers do not use educational opportunities of modern technical devices, electronic educational resources and network services appropriately. In particular, $32 \%$ of technology teachers (among 125 respondents) showed knowledge and understanding of the main features of the modern ISTE lesson.

In this regard, the actual task of the higher pedagogical education is to correlate the level of technology teachers training to professional activities in ISTE and the requirements for modernizing general and pedagogical education.

The analysis of the scientific recourses has shown the large number of studies in the field of the theory and methodology of preparing future teachers for the ICT use. Conventionally, there are two periods of the studies: the period associated with the beginning of ICT use in education (1995-2005) and the period of formation and development of information and education space (2006-2016).

The first studies (Grinskun, 2013), (Lapchik, 2012) in this field were related to the preparing future teachers of computer science. The most modern researches are focused on the preparation of future 
teachers for professional activities in the conditions of rapid development of communication tools, mobile and multimedia technologies (Alexandrova, 2008), (Nass, 2013) and the formation of teachers' readiness for professional interaction through the Internet (Gotha, Zhuchkov 2001). During this period, the researchers considered certain problems of preparing future teachers for the use of ICT in various subject areas: foreign languages, physics, mathematics, etc.

The researches (Akhmetov, 2008), (Bogatyrev, 2003), (Voronin, 2003) have made a great contribution to the problem of preparing technology teacher for the use of ICT. The scientific works were carried out in 1995-2010, and they did not take into account the current level of the information space and did not reflect the new requirements for the professional work of technology teachers.

Thus, the following problems arise: What is the description of the training system of technology teachers for professional activity in the ISTE? Does it meet the requirements for a modern information society and take into account the trends of general and pedagogical education?

\section{Methods of the Research}

The purpose of the research is theoretical justification, creation and implementation of the methodological system of preparing technology teachers for ICT use at their further professional activities.

The methodological basis of the study is activity, system, personal, space, competence and professionally oriented approaches. The methodological approaches are interdependent. We consider the approaches in conjunction with each other.

The following research methods were used to achieve the purpose of the research and solve the set tasks:

theoretical - analysis of philosophical-methodological, pedagogical, psychological, methodical literature devoted to modern problems of education; general scientific methods (system analysis, comparison, synthesis, specification, modeling, comparison, systematization, generalization);

experimental - questioning, testing, observation, interviewing, studying the products of students and technology teachers' activities, peer review, experimental work, personal teaching, statistical methods for processing experimental data.

The experimental work was carried out in 2008-2018. The participants of the pedagogical experiment were 850 technology teachers from 28 Russian regions, 620 students and 57 teachers from universities of Russia, Ukraine and the USA. The developed model of the methodological system was tested at Pitirim Sorokin Syktyvkar State University, Moscow Pedagogical State University, Perm State Humanitarian Pedagogical University and Vyatka State University.

The study was conducted in three stages:

The following studies were carried out at the first stage: analysis and synthesis of scientific and methodological works related to current trends in the development of education in the context of the global development of ICT in the world and in Russia; analysis of regulatory documents on the problems of modern basic general and higher pedagogical education in Russia; comparative analysis of state educational standards of higher education and educational programs.

The theoretical, methodological and methodical bases of the research were developed at the second stage. The analysis of the teacher professional standard and federal educational standards determined the list of professional actions of technology teacher in the field of ICT. We formulated the main conceptual provisions for the methodological system; defined the stages of formation of the future 
technology teacher's readiness for professional activities in ISTE and developed teaching and methodological support for each stage of preparation.

The performance of the developed methodological system was checked at the final stage and the results of the research were summarized in monographs and teaching aids.

\section{Results}

The basis of the methodological system for preparing technology teacher for professional activities in ISTE are the analysis of the problems of modern information-education space, study of scientific works and examination of the existing system of technology teacher training in Russian universities.

Conceptual provisions are the following:

1) ISTE is created and developed in the process of pedagogical interaction between the subjects of the educational process by means of new forms at school, regional and all-Russian levels;

2) formation of readiness should be considered as a focused, step-by-step, pedagogically controlled process of formation of the future technology teacher as an individual, the subject of educational activity and the subject of ISTE;

3) readiness is defined as an integral quality of a person, characterized by a multi-level and multicomponent structure, which manifests itself in the striving and ability to carry out professional actions in solving general-tactical and private-methodical tasks using ICT tools in technology training;

4) the methodological system should be considered as a subsystem of subject and methodological training of technology teacher in the system of higher education;

5) implementation of the methodological system is based on the idea of professional formation of the future teacher through the gradual formation of readiness;

6) it is advisable to base educational process on the activity approach with the unity of the main types of educational activities.

On the basis of the concept, we proposed the model of the methodological system of preparing technology teacher for professional activity in ISTE (Fig. 1).

The first block is represented by external factors influencing the creation and development of the methodological system - these are governmental programs, strategies, regulatory and legal documents. 


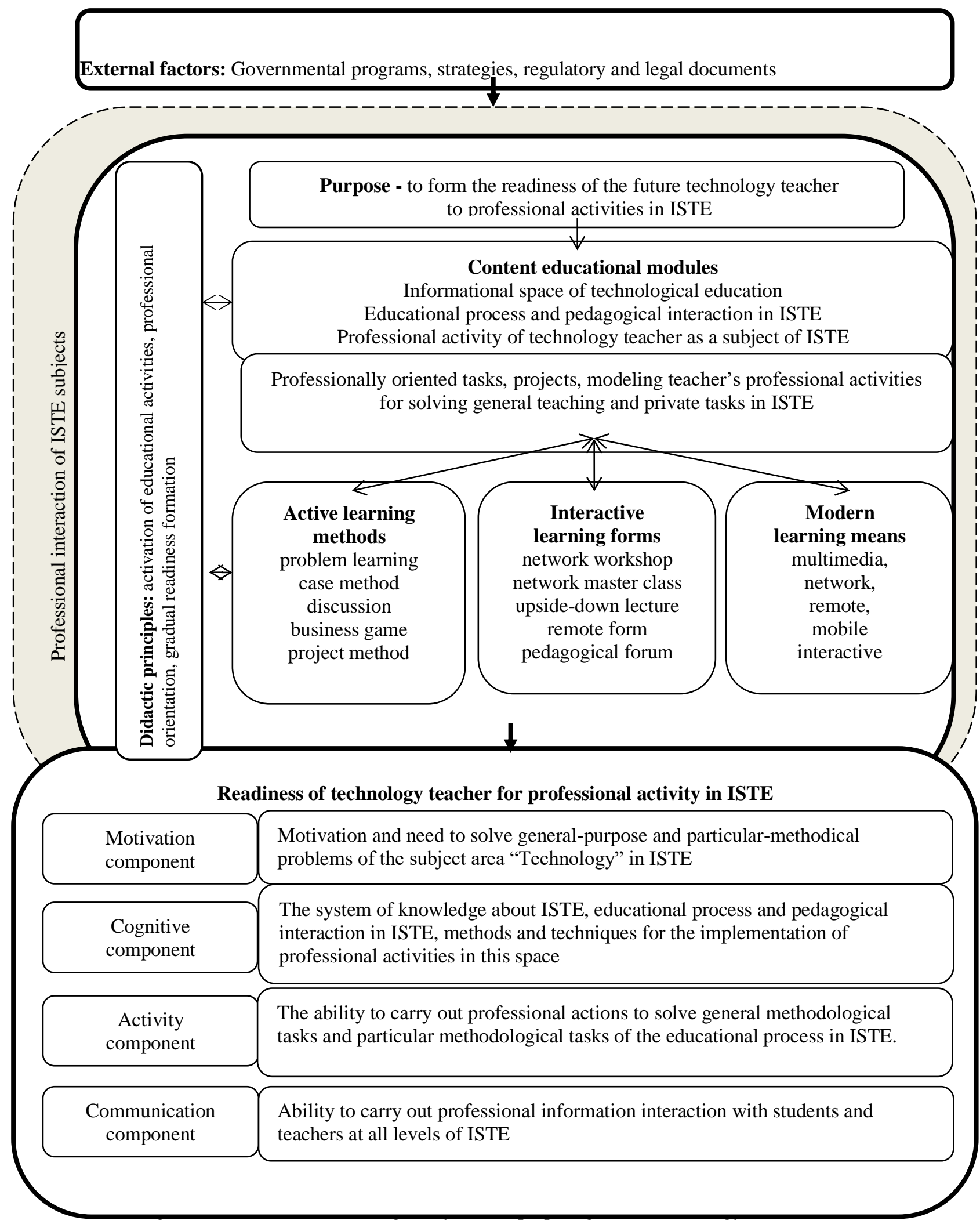


The second block is the content-organizational block, where the integrity of the methodological system is provided by the interrelations between its components: purpose, content, set

of tasks, active methods, interactive forms and modern teaching aids and didactic principles, which are the unifying component.

The third block presents the structure of readiness, which includes: motivation, cognitive, activity and communication components.

The important condition for methodological system is the organization of interaction of the future technology teacher with the subjects of ISTE. The interaction is carried out within the teaching practice, networking events and the network community.

The content of preparing technology teachers for professional activity in ISTE is projected on the basis of the modules: Information space of technological education. Educational process and pedagogical interaction in ISTE. Professional activity of technology teacher as a subject of ISTE. The selected modules define the content and the stages of preparation and correspond with the main stages of the professional development of a future teacher.

The implementation of the methodological system at all training stages should facilitate the transition from academic activities to education-professional activities and in the final outcome - to the development of professional activities. It is necessary to create conditions for the development of all components of readiness at every training stage.

The phased implementation of the methodological system allows to integrate psychological, pedagogical, methodical and subject knowledge and skills of students, to prepare future technology teachers for professional activities in ISTE during pedagogical practice in a specific educational organization and to hold research work on the problem of ICT of technological education.

The implementation of the methodological system is carried out in the process of organizing educational, cognitive, educational, professional and research activities of students, with the leading type of educational activity being distinguished at each stage of preparation. Types of students' learning activities are interrelated with a certain set of teaching methods, interactive forms and modern teaching aids using electronic, interactive, mobile and distance technologies. It should be noted that interactive forms and modern teaching aids should be optimally combined with traditional forms and teaching aids (Table 1).

Table 1

Interrelation of training stages

with the leading types of learning activities, methods, forms and means

\begin{tabular}{|c|c|c|c|c|c|}
\hline$\underset{\mathscr{E}}{\mathbb{E}}$ & Content & $\begin{array}{l}\text { Leadin } \\
\text { g form of } \\
\text { students' } \\
\text { learning } \\
\quad \text { activit } \\
y\end{array}$ & $\begin{array}{r}\text { L } \\
\text { earning } \\
\text { m } \\
\text { ethods }\end{array}$ & $\begin{array}{l}\text { Interactive } \\
\text { learning forms }\end{array}$ & $\begin{array}{r}\text { Modern } \\
\text { learningl means }\end{array}$ \\
\hline
\end{tabular}




\begin{tabular}{|c|c|c|c|c|c|}
\hline 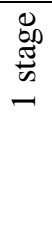 & $\begin{array}{l}\text { Informati } \\
\text { onal space of } \\
\text { technological } \\
\text { education }\end{array}$ & $\begin{array}{l}\text { Educati } \\
\text { onal-cognitive }\end{array}$ & $\begin{array}{l}\text { Pr } \\
\text { oblem } \\
\text { method }\end{array}$ & $\begin{array}{l}\text { Inverted lecture } \\
\text { Network } \\
\text { workshop } \\
\text { Network } \\
\text { master-class }\end{array}$ & $\begin{array}{l}\text { Interacti } \\
\text { ve board } \\
\text { Interacti } \\
\text { ve systems } \\
\text { Docume }\end{array}$ \\
\hline 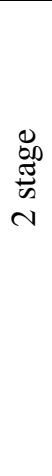 & \begin{tabular}{l}
\multicolumn{2}{r}{ Educatio } \\
nal process and \\
pedagogical \\
interaction in \\
ISTE
\end{tabular} & $\begin{array}{l}\text { Educati } \\
\text { onal- } \\
\text { professional } \\
\quad \text { Scientif } \\
\text { ic-research }\end{array}$ & \begin{tabular}{l}
\multicolumn{1}{c}{ C } \\
ase method \\
oject \\
method \\
$\qquad \begin{array}{l}\text { B } \\
\text { usiness } \\
\text { game }\end{array}$
\end{tabular} & $\begin{array}{l}\text { Remote } \\
\text { workshop } \\
\text { Network } \\
\text { workshop } \\
\text { Competition of } \\
\text { methodological materials } \\
\text { Festival of } \\
\text { educational web-sites } \\
\text { Professional } \\
\text { tests in ISTE }\end{array}$ & $\begin{array}{l}\text { nt camera } \\
\text { The } \\
\text { system of } \\
\text { operational } \\
\text { knowledge } \\
\text { control Mobile } \\
\text { devices Means of } \\
\text { communication }\end{array}$ \\
\hline 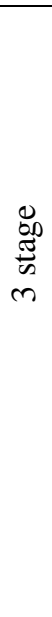 & $\begin{array}{l}\text { Professio } \\
\text { nal activity of a } \\
\text { technology } \\
\text { teacher as a } \\
\text { subject of ISTE }\end{array}$ & $\begin{array}{l}\text { Educati } \\
\text { onal- } \\
\text { professional } \\
\quad \text { Scientif } \\
\text { ic-research }\end{array}$ & $\begin{array}{l}\quad \text { C } \\
\text { ase method } \\
\qquad \begin{array}{l}P r \\
\text { oject }\end{array} \\
\text { method }\end{array}$ & $\begin{array}{c}\text { Pedagogical } \\
\text { practice } \\
\text { Remote } \\
\text { pedagogical } \\
\text { forum } \\
\text { Remote } \\
\text { discussion platform } \\
\text { Remote } \\
\text { scientific conference }\end{array}$ & $\begin{array}{l}\text { Electroni } \\
\text { c educational } \\
\text { resources } \\
\text { Network } \\
\text { educational } \\
\text { services } \\
\text { Distance } \\
\text { learning system } \\
\text { The } \\
\text { system of remote } \\
\text { support of } \\
\text { pedagogical } \\
\text { practice }\end{array}$ \\
\hline
\end{tabular}

At the first stage of preparation, when studying the content of the module "Information Space of Technological Education", future teachers of technology consider ISTE as a necessary condition for implementation the main educational program; highlight the role and place of ISTE in the hierarchical structure of information-education space; get acquainted with the concept "information-education space of technological education"; study the main components of ISTE, determine its specificity in the subject area "Technology" and factors affecting the developing nature of the space.

At this stage, there is the formation of motivational and cognitive component of readiness to professional activity in ISTE and the ways of performing professional actions in ISTE.

The leading type of educational activity is educational-cognitive activity, which has a professional orientation. In this regard, all types of tasks (analytical and research tasks, modeling tasks) should be related to the content and specificity of the subject area "Technology". Analytical tasks are aimed to analyze regulatory documents; electronic educational recourses on technology; programs of formation and development of ISTE in specific educational organizations. Future technology teachers are invited to conduct mini-studies to identify the components of the information infrastructure, modern ICT tools and 
electronic tools for managing the learning process.

At the end of the first stage, future technology teachers should develop ISTE model for 5-7 (8-9) grades, including all the components and reflecting the ways and forms of pedagogical interaction between a technology teacher and students at both curricular lessons and extracurricular activities.

Various interactive forms (inverted lecture, network workshop, network master class) are used to organize the interaction between university teacher and students. Students can study the training material, post the results of completed assignments and teaching materials, discuss and evaluate them after class.

The second stage of preparation is the formation of cognitive, activity-related and communicative components of readiness and ways of performing professional actions on the organization of the educational process and pedagogical interaction in ISTE for solving general-purpose and particularmethodical tasks.

The leading activities at this stage are educational, professional and research activities that are carried out by means of project and research tasks, case studies and essays. Cases for solving methodological and technical tasks are aimed at modeling professional activities and pedagogical situations that may arise in real life. Project tasks are aimed at developing interactive training sessions, methodological tools for monitoring students' knowledge, modern audiovisual teaching materials, network educational resources on technology, etc.

Students visit basic educational institutions, where they observe technology teachers and educational process in ISTE. They study educational websites for teachers, analyze interaction process in a network project, distance contest. Students and practicing technology teachers interact, conducting the network workshop "Network services for educational activities to study technology". Working in creative groups, students and teachers study and analyze network educational services, develop educational resources for solving general teaching and private methodological problems. Thus, at the second stage, future technology teachers form the holistic view about the organization of educational process and the implementation of pedagogical interaction in ISTE.

The final stage is characterized by formation of methods for professional activities in ISTE in educational-professional and research activities. There is the active interaction with students in specific professional situations (interactive lessons and educational games, online training projects, distance and subject contests on technology at the municipal, regional and all-Russian levels) and with technology teachers (all-Russian Pedagogical Forum, remote conferences, competition of methodological developments "Technology Lesson for the New School", festival of educational sites, discussion sites).

Students make the significant number of tasks during educational-professional activities of teaching practice. The remote support system for teaching practice, consisting of three interrelated components (informative, organization, communication), has been developed and tested to overcome informational isolation and organization of interaction between students and teachers.

The introduction of the developed model of the methodological system was carried out during the pedagogical experiment.

At the ascertaining stage, we analyzed the training system of future technology teachers at Russian universities, the attitude of technology teachers to the design and implementation of the educational process in ISTE, the level of readiness of future and practicing technology teachers to professional activity in ISTE, methodological developments on technology using ICT.

The result of the ascertaining stage of the pedagogical experiment confirmed the hypothesis that there are certain methodological problems in preparing future technology teachers for professional activity 
in ISTE and substantiated the need to improve the training by building the methodological system. During the search stage of the pedagogical experiment, we developed and studied the content of preparing technology teacher for professional activity in ISTE; identified and tested active methods, interactive forms and modern teaching aids.

The research singled out and justified one of the effective forms of professional interaction between university teachers, students and technology teachers of technology - The All-Russian Distance Pedagogical Forum with international participation "Information and communication space of technological education". It included the conference "Technology education in terms of ICT"; the methodological competition "Technology lesson for the new school"; Festival of educational technology web-sites; discussion of web-sites; workshops. More than 530 participants from various regions of the Russian Federation, Ukraine and the USA took part in the pedagogical forum in 2014-2017 (histogram 1).

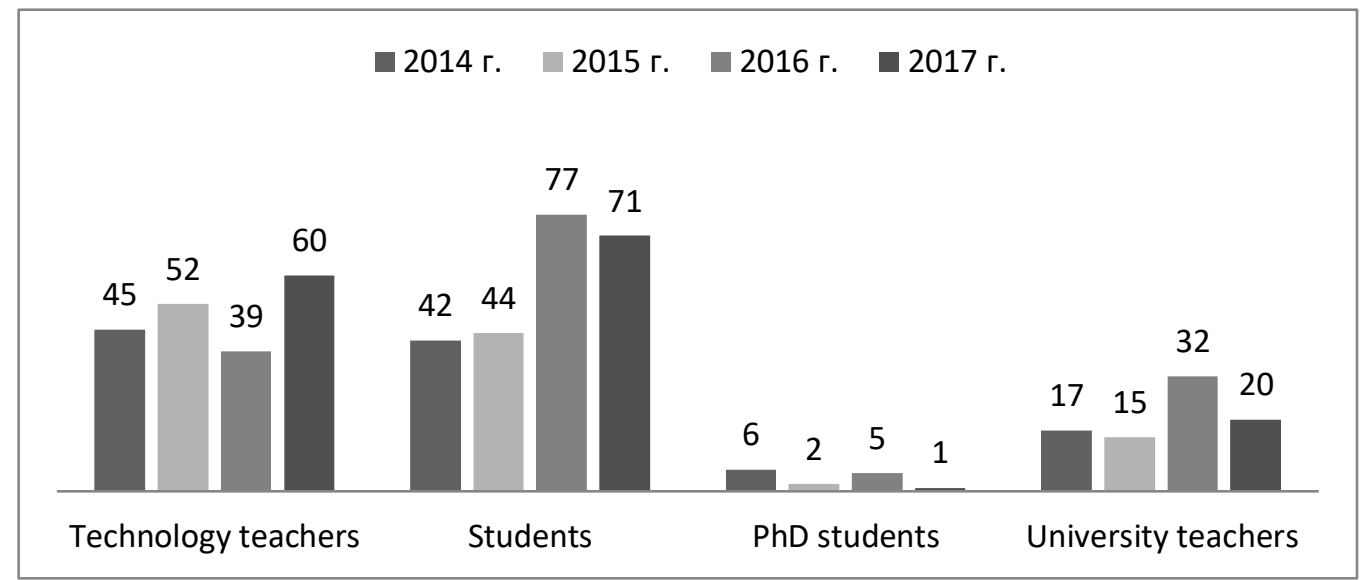

Histogram 1. Participants of the All-Russian Pedagogical Forum

"Information and communication space of technological education"

The heightened interest to the forum, the increasing number of participants and their activity made the forum the innovative form for the professional development of future technology teacher in information space of technological education.

During the formative stage of the experiment (2014-2017), we studied the level of readiness of the future technology teachers for professional activities in ISTE.

The tasks of the formative stage were to identify and compare the level of students' readiness in experimental and control groups, implement the methodological system and evaluate the results of the experiment. 98 students from Pitirim Sorokin Syktyvkar State University (Syktyvkar) and Perm State Humanitarian Pedagogical University (Perm) took part in the formative stage of the experiment. The study was based on the developed program for determining the level of readiness of future technology teachers for professional activities in ISTE (Table 2) at both the beginning and the end of the formative stage of the experiment.

Table 2

Program for evaluation technology teachers' readiness

for professional activities in ISTE 


\begin{tabular}{|l|l|l|}
\hline \multirow{2}{*}{$\begin{array}{c}\text { Levels of components of } \\
\text { technology teacher readiness for }\end{array}$} & Motivation & Questioning \\
\cline { 2 - 3 } professional activities in ISTE & Cognitive & Testing \\
\cline { 2 - 3 } & Activity & Expert review \\
\cline { 2 - 3 } & Communication & $\begin{array}{c}\text { Analysis of the results of the } \\
\text { interaction between ISTE subjects }\end{array}$ \\
\hline
\end{tabular}

The obtained data was converted from a non-metric scale to an interval scale according to the Rasch model. The formula $D=\ln \left(\frac{P}{1-P}\right)$ determined the $\mathrm{D}$ value for each component of readiness. The level of readiness components was set depending on the obtained $D$ values: non-readiness $\left(D_{i}<0\right)$, low $(0 \leq$ $\left.D_{i}<1\right)$, medium $\left(1 \leq D_{i}<2\right)$, high $\left(D_{i} \geq 2\right)$. The integral readiness factor was used to determine the level of readiness of technology teacher for professional activity in ISTE. It was defined as the sum of the values for motivation, cognitive, activity and communication components of readiness (chart 1).

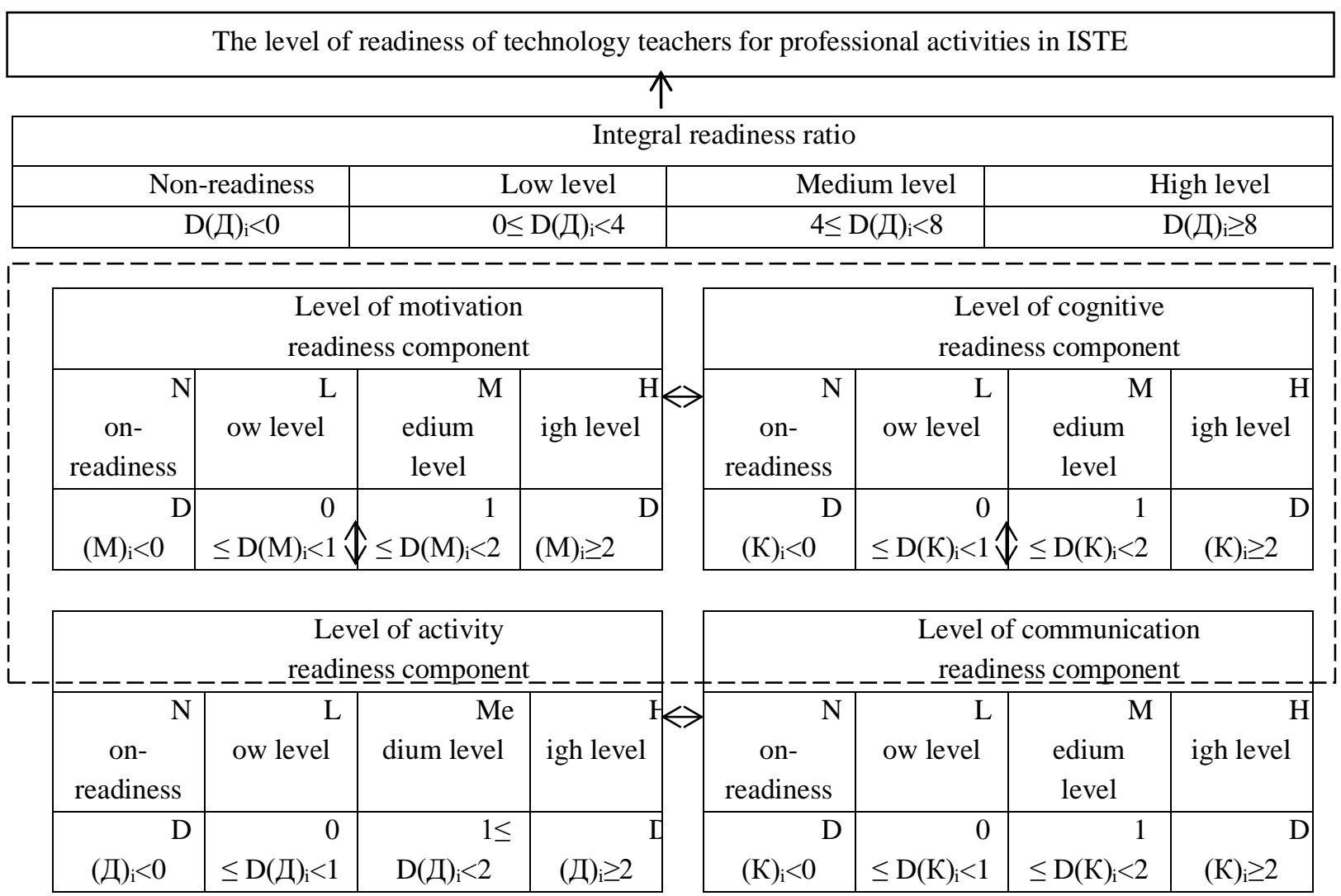

Chart 1. Determining the level of readiness of technology teacher for professional activities in ISTE

The comparative analysis of the results of the integral readiness ratio at the beginning and the end of the formative stage of the experiment showed that the students of the experimental group had the higher level of readiness for professional activity in ISTE (histogram 2). 


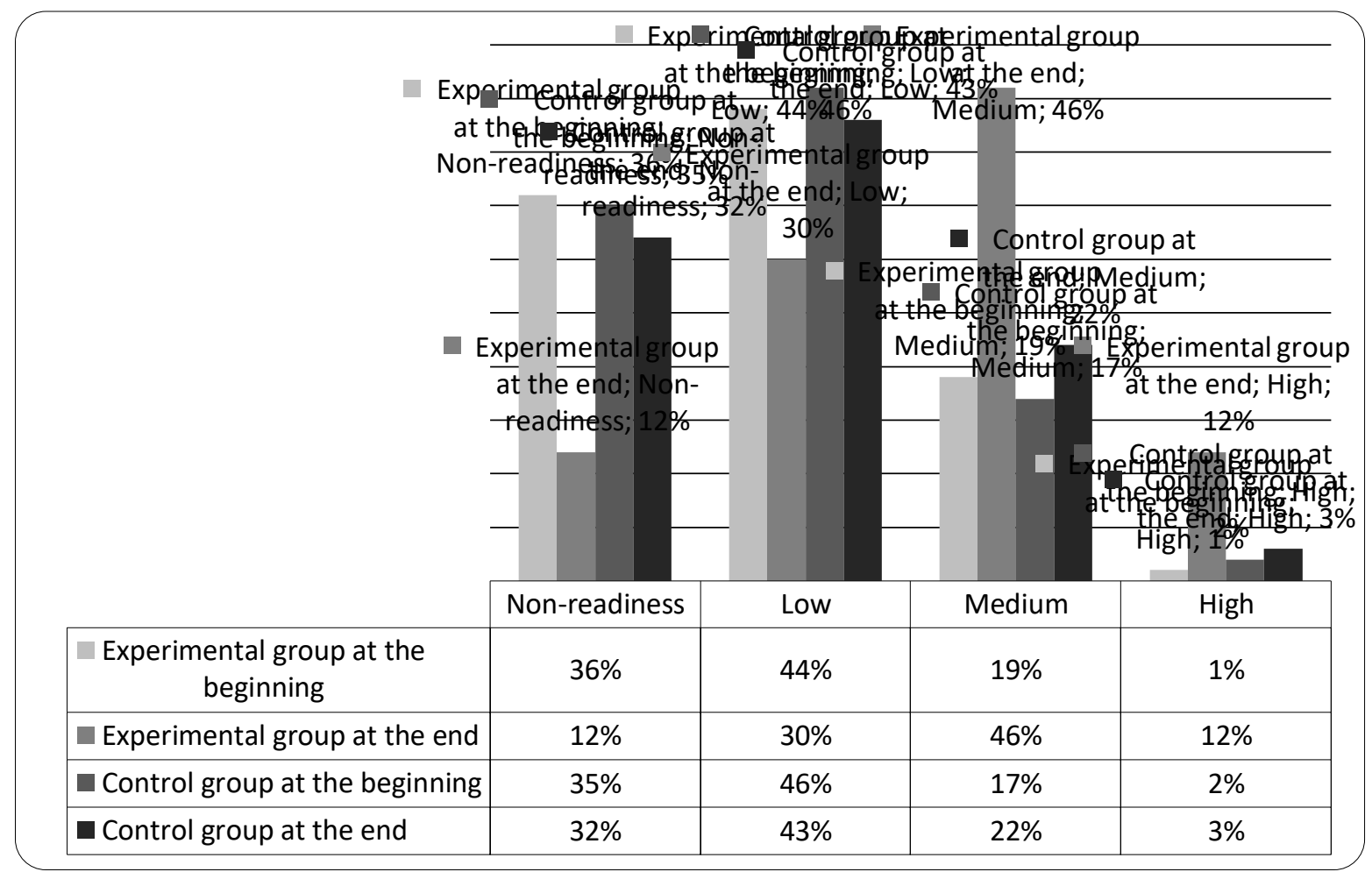

Histogram 2. Dynamics of readiness level

of future technology teachers for professional activities in ISTE

Another confirmation of a higher level of readiness for professional activities among students of the experimental group is private achievements in the research activities and further magistracy education in the direction "Pedagogical education" (Table 3).

Table 3

Achievements of students of experimental and control groups

\begin{tabular}{|l|c|c|}
\hline Achievements of students & $\begin{array}{c}\text { Experimental } \\
\text { group } \\
(45 \text { students })\end{array}$ & $\begin{array}{c}\text { Control } \\
\text { group } \\
\text { (44 students) }\end{array}$ \\
\hline Network community activity & 38 & 21 \\
\hline Participation in contests / festivals & 42 & 36 \\
\hline Winners of contests / festivals & 11 & 2 \\
\hline Participation in scientific conferences & 24 & 13 \\
\hline Publications in scientific journals & 16 & 2 \\
\hline Further magistracy education & 12 & 4 \\
\hline
\end{tabular}

Thus, the results of the study indicate the increased level of readiness of the future technology teachers for professional activities in ISTE and indicate the feasibility of implementing the developed methodological system. The experimentally obtained results confirm the hypothesis of the study. 


\section{Questions to Discuss}

How much can modern digitalization of all social spheres affect the system of university education of future technology teachers? How can technology teacher influence the development of the information-education space of a particular educational institution in the conditions of modern school education? What is the teacher's role in the development of the regional education system?

\section{Conclusion}

The result of the research is the proposed system of methodological preparation of technology teachers, which has been tested at the domestic and foreign levels. The conceptual ideas and concrete implementation are as follows.

1. We highlighted constant and variable functions in the structure of ISTE; suggested the new forms of pedagogical interaction between technology teacher and students within integrating educational and extracurricular activities; propose innovative forms of learning interaction (interactive educational journey, interactive cognitive game, interactive lesson, remote subject contests on technology); suggested the method of using electronic educational resources at technology lessons.

2. For the first time, we highlighted and justified the set of professional actions of technology teacher in solving pedagogical problems in technological education. The variants of practical application of this complex are proposed for filling the professional standard of a teacher.

3. The conceptual basis of the methodological system of preparing technology teacher for professional activity in ISTE is the following: 1) the preparation of students is carried out with the active interaction of ISTE subjects; 2) the gradual formation of the technology teachers' readiness to work in the information space ensures the transition from educational activity to motivated professional activity; 3 ) pedagogical conditions for modeling professional actions were created in accordance with the requirements of the teacher's professional standard and the specifics of the subject "Technology".

4. The implementation of the training program is carried within the content modules (educational process and pedagogical interaction in ISTE, professional activities of technology teacher as the subject of ISTE); professional-oriented tasks (analytical, research and design, modeling, solving methodological situations, writing essays, professional tests); active teaching methods (problem teaching, case method, discussion method, project method), modern teaching aids (multimedia, interactive, distance, mobile) and interactive forms (inverted lecture, network master class, workshop, remote pedagogical forum).

5. The system for assessing the readiness of technology teachers for professional activity in ISTE has been proposed and tested.

6. The developed program of gradual preparation of the future technology teachers for professional activity in ISTE is fully implemented in five Russian regions.

\section{References}

Aceto, S., Dondi, C. \& Marzotto, P. (2010). Pedagogical Innovation in NewLearning Communities: An Indepth of Twdyelve Online Learning Communities. http://hal.archivesouvertes.fr/docs/00/59/30/45/PDF/JRC59474.pdf

Alexandrova, N.V. (2008). Training future teachers of humanities to use and create electronic educational resources. Yekaterinburg.

Akhmetov, L.G. (2008). Information environment of the professional activity of technology teacher: 
problems of design. Kazan

Bogatyrev, A.N. (2003). The main directions of the development of methods of information-technological training of future technology teachers. Tekhnologiya, tvorchestvo, lichnost' - Technology, creativity, personality. Kursk: Kurskij gosudarstvennyj universitet, 8-10.

Gotskaya, I.B. Zhuchkov, V.M. (2001). Readiness for professional pedagogical activity as a result of the functioning of the educational program. Nauka i shkola - Science and School, 3.18-23.

Grinshkun, V.V. (2013). The quality of information resources and professional qualities of teachers. Relationship and problems. Informatika i obrazovanie - Computer science and education. 1, 7981.

Lapchik, M.P. (2012). ICT-competence of bachelors of pedagogical direction. Informatika i obrazovanie Computer science and education. 2, 29-32.

Law (2012). Federal Law on December 29, 2012 No. 273-FZ on Education in the Russian Federation ". Russian newspaper. 5976.

Nass, O.V. (2013) Theoretical-methodological foundations of the formation of the competence of teachers in the field of creating electronic educational resources. Moscow.

Order (2015). Order No. 1426 of December 4, 2015 approving the Federal State Educational Standard of Higher Education in the direction of training 44.03.01 Pedagogical education (undergraduate level) [Order No. 1426 of December 4, 2015 approving the Federal State Educational Standard of Higher Education 44.03.01 Pedagogical education (baccalaureate level)] .- http: //minobrnauki.rf/documents/7995.pdf

Order (2013). Order of October 18, 2013 No. 544n on the approval of the professional standard "Teacher (pedagogical activity in the sphere of pre-school, primary general, basic general, secondary general education) (educator, teacher). Psychological science and education. 3, 11-31.

Garet, M. S., Porter, A. C., Desimone, L., Birman, B., \& Yoon, K. S. (2001). What makes professional development effective? Results from a national sample of teachers. American Education Research Journal, 38, 915-945.

UNESCO ICT Competency Framework for Teachers. Published in 2011 by the United Nations Educational, Scientific and Cultural Organization 7, place de Fontenoy, 75352 PARIS 07 SP. http://unesdoc.unesco.org/images/0021/002134/213475e.pdf

Voronin, Yu.A. (2003). Computerization of physical-technical training of teacher technology. Voronezh. 